\title{
IMPLEMENTASI AUGMENTED REALITY UNTUK PEMBELAJARAN INTERAKTIF
}

\author{
Dedy Atmajaya \\ dedy.atmajaya@umi.ac.id \\ Universitas Muslim Indonesia
}

\begin{abstract}
Abstrak
Penelitian ini menyajikan implementasi augmented reality (AR), untuk pembelajaran interaktif anak usia dini. Dengan menerapkan konsep AR pada metode pembelajaran anak usia dini, diharapkan dapat menciptakan suasana belajar yang menarik dan menyenangkan. Karena dengan menerapkan konsep AR pada metode pembelajaran para guru atau orang tua dapat menciptakan suasana belajar yang lebih nyata kepada anak dengan ditampilkannya objek 3D, serta improvisasi suara dan gambar yang mendukung suasana pembelajaran. Diharapakan metode ini dapat menjawab permasalahan utama dalam hal pembelajaran anak usia dini yaitu menarik fokus dan perhatian mereka. Hasil penelitian ini adalah prototipe sistem/aplikasi AR untuk metode pembelajaran interaktif bagi anak, yang dapat digunakan untuk pembelajaran pengenalan hewan dan buah-buahan baik di lingkungan lembaga pendidikan atau untuk pendidikan secara mandiri bagi orang tua. Dalam mengimplementasikan Aplikasi AR digunakan tools gimp, unity3D, blender dan vuforia.
\end{abstract}

Kata kunci: pembelajaran interaktif, augmented reality, unity3D, vuforia

\section{Pendahuluan}

Pada hakikatnya, pendidikan merupakan usaha manusia memanusiakan manusia dan membudayakan manusia. Oleh sebab itu tahapan pendidikan dapat dilakukan mulai dari tahapan paling awal (usia dini) sampai akhir hayat. Pada umumnya Pendidikan Anak Usia Dini (PAUD) diselenggarakan melalui 3 jalur yaitu, jalur pendidikan formal, jalur pendidikan non formal, jalur pendidikan informal[1]. Menurut Undang-Undang Nomor 20 Tahun 2003 tentang Sistem Pendidikan Nasional, menyatakan bahwa pendidikan anak usia dini adalah salah satu upaya pembinaan yang ditujukan untuk anak sejak lahir sampai dengan 6 tahun yang dilakukan melalui pemberian rangsangan pendidikan untuk membantu pertumbuhan dan perkembangan jasmani dan rohani agar anak memiliki kesiapan dalam memasuki jenjang pendidikan lebih lanjut [1]. PAUD berfungsi membina, menumbuhkan dan mengembangkan seluruh potensi anak usia dini secara optimal sehingga terbentuk perilaku dan kemampuan dasar sesuai dengan tahap perkembangannya sebagaimana tercantum dalam Permendiknas No 58 Tahun 2009 meliputi nilai-nilai agama dan moral, social emosional, fisik, kognitif, dan bahasa.

Tahap-tahap perkembangan bermain anak usia dini, menurut Mildred Parten melalui 6 tahap yaitu[2] :

1. Unoccupied Behavior / Gerakan Kosong

Anak sepertinya belum melakukan kegiatan bermain, hanya mengamati sesuatu sejenak saja. Misalnya bayi mengamati jari tangan atau kakinya sendiri dan menggerakannya tanpa tujuan.

2. Onlocker Behaviour / Tingkah laku pengamat

Anak memperhatikan anak yang lain yang sedang melakukan suatu kegiatan atau sedang bermain. Misalnya seorang anak yang memperhatikan temannya sedang bermain petak umpat, tanap ia ikut bermain tetapi ia turut merasa senang seolah ia ikut bermain.

3. Solitary Play / Bermain Soliter

Anak bermain sendiri mencari kesibukan sendiri, tanpa perduli dengan orang lain/teman lain yang ada disekitarnya.

4. Parralel Play / Bermain Paralel

Anak melakukan kegiatan bermain di antara anak yang lain tanpa ada unsur saling mempengaruhi. Misalnya anak bermain puzzle dan anak lain juga bermain puzzle, mereka ada bersama tetapi tidak saling mempengaruhi.

5. Associative Play / Bermain Asosiatif

Anak melakukan kegiatan bermain bersama anak lain tetapi belum ada pemusatan tujuan bermain. Misalnya beberapa anak bermain menepuk-nepuk air di kolam bersama- sama.

6. Cooperative Play / Bermain Koperatif 
Anak melakukan kegiatan bermain bersama-sama dengan teman secara terorganisasi dan saling bekerja sama, ada tujuan yang ingin dicapai bersama dan ada pembagian tugas yang disepakati bersama. Misalnya bermain rumah-rumahan ada yang jadi bapak, ibu dan anak, masing-masing memiliki tugas. Anak membuat rumah-rumahan tersebut dengan kain atau balok-balok dan bermain peran dengan boneka.

Berdasarkan perkembangan bermain anak menurut Mildred Parten, fokus penelitian ini ada pada tahap parallel play, assosiative play dan cooperative play. Dengan menggunakan media teknologi sebagai alat bantu untuk menarik fokus perhatian anak. Selain pada pemanfaatan teknologi objek-objek yang menjadi pusat pembelajaran/pengenalan di susun sebaik mungkin sesuai dengan lingkungan sekitar peserta didik. Sebagai contoh objek yang digunakan adalah pengenalan hewan dan buah-buahan. Di mana objek-objek tersebut dapat dengan mudah di temui oleh si anak, sehingga dapat terjadi keberlangsungan pembelajaran pada anak tersebut.

Penggunaan teknologi yang dimaksud adalah Augmented Reality (AR), yang merupakan sintesis perumpamaan nyata dan virtual[3]. Aplikasi AR telah banyak diterapkan di berbagai aspek kehidupan, salah satu yang paling banyak adalah bidang pendidikan. Secara umum AR adalah konsep aplikasi yang menggabungkan dunia fisik (objek sesungguhnya) dengan dunia digital, tanpa mengubah bentuk objek fisik tersebut[4]. Pengenalan objek (gambar) yang digunakan untuk menampilkan berbagai informasi mengenai objek tersebut berupa gambar 3D dan suara sesuai dengan karakter objek gambar. Augmented reality sebagai sebuah sistem kognitif dan mampu memahami secara utuh persepsi dari pengguna [5].

Tujuan penelitian ini adalah untuk mengembangkan media pembelajaran dengan memanfaatkan teknologi Augmented Reality, sehingga proses pembelajaran diharapkan lebih interaktif dengan dukungan visualisasi secara 3D untuk gambar, serta improvisasi suara untuk menciptakan realitas nyata pada proses pembelajaran. Objek pembelajaran yang dilakukan pada penelitian ini ditujukan kepada anak usia dini, baik yang tergabung melalui lembaga-lembaga pendidikan khusus untuk anak usia dini (PAUD), ataupun anak-anak secara mandiri dapat belajar dengan di damping oleh orang tua (/orang dewasa lain).

\section{Metode}

\subsection{Kebutuhan Pengguna}

Dalam mengembangkan bahan ajar untuk proses pembelajaran peneliti selalu melakukan komunikasi dengan beberapa lembaga PAUD, untuk menciptakan konten yang baik sesuai dengan kaidah pembelajaran pada anak usia dini. Beberapa tujuan pembelajaran yang perlu diperhatikan dalam menampilkan objek ke bentuk 3D diantaranya:

1. Pengguna dapat dengan mudah mengenali/menyebutkan objek yang ditampilkan.

2. Pengguna mendapatkan clue, berupa suara untuk membantu mengenali objek 3D.

3. Pengguna mendapatkan tampilan 3D, sesuai objek yang dipilih.

\subsection{Kebutuhan Sistem dan Implemetasi}

Spesifikasi minimum perangkat yang dibutuhkan untuk mendukung penelitian ini adalah:

2.2.1. Laptop dengan Spesifikasi:

- Processor Core i3

- Webcam dengan resolusi minimum 320x240 pixel

- VGA Card $128 \mathrm{MB}$

- Ram 2GB

- Hard Disk 320GB

- Printer

2.2.2. Smartphone Android dengan Spesifikasi :

- Minimum OS 2.1

- Device powered by an ARMv7 (Cortex Family) CPU

- GPU support for OpenGLES 2.0 (Recommended)

Berikut ini perupakan perangkat lunak pendukung penelitian ini adalah:

- Blender (digunakan untuk membuat/mendesain objek 3D).

- Gimp (digunakan untuk membuat/mendesain objek gambar (".jpg, *.png).

- Vuforia (digunakan untuk membuat objek marker).

- Unity 3D (digunakan untuk membuat Aplikasi Augmented Reality-AR). 


\subsection{Perancangan Sistem}

Dalam mengimplementasikan penelitian ini, peneliti lebih fokus menggunakan tools open source seperti Unity 7 , sebagai framework utama untuk menbangun Aplikasi AR. Alur proses dari aplikasi AR yang dikembangkan dapat dilihat pada flowchart Gambar 1. Tahapan pertama dimulai dengan pemilihan model penanda (marker). Model marker terbagi kedalam 2 bentuk pelacakan, yaitu; image tracking dan object tracking. Kemudian marker yang telah dipilih kemudian dilakukan rendering atau penyatuan gambar dengan environment yang kemudian disimpan ke dalam AR Store. Proses berikutnya yaitu proses menampilkan object 3D.

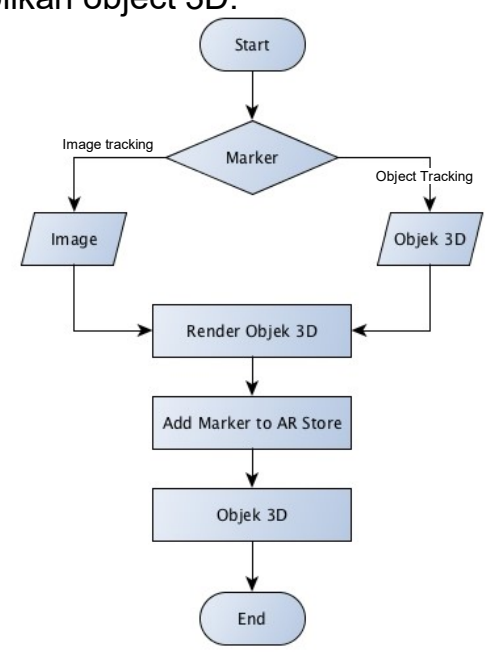

Gambar 1. Flowchart Aplikasi AR[4]

Use Case Diagram Aplikasi AR.

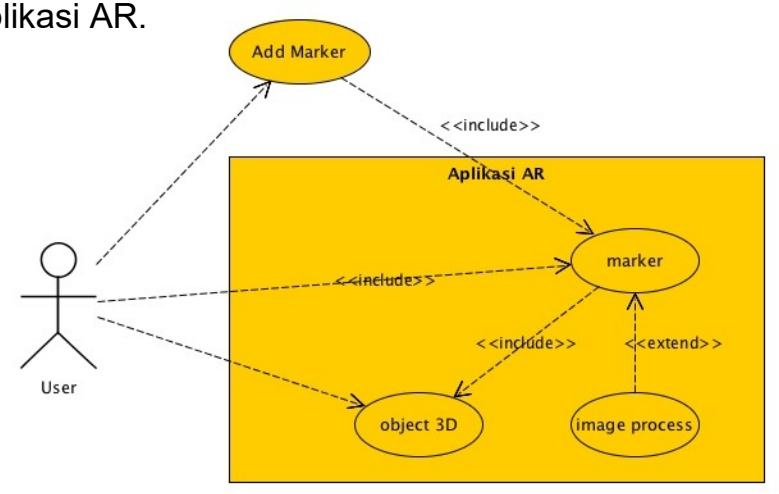

Gambar 2. Use Case Diagram Aplikasi AR

Gambar 4 menunjukkan desain use case diagram dalam aplikasi AR. Pengguna tinggal mengarahkan kamera pada laptop atau handphone androidnya, kemudian object marker diarahkan di depan kamera. Jika posisi marker telah presisi/fokus, maka objek 3D akan tampil di layar, di ikuti dengan clue suara sesuai dengan objek marker yang di pilih oleh pengguna.

\subsection{Perancangan Aplikasi}

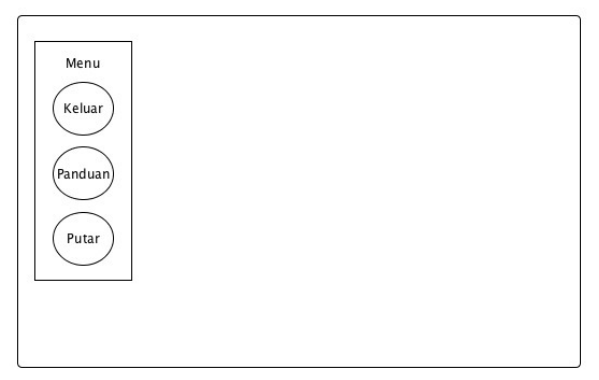


Gambar 3. Desain Utama Antarmuka Aplikasi AR

Gambar 3 menjelaskan desain antarmuka utama pada saat Aplikasi AR dijalankan. Terdapat tiga tombol utama dalam menu, yaitu :

- Exit : untuk keluar dari program AR.

- Panduan : untuk menampilkan panduan, posisi marker

- Putar : digunakan untuk memutar $360^{\circ}$, objek 3D.

\section{Hasil dan Pembahasan}

Pada bagian ini akan dijelaskan konsep prototipe desain dan pengembangan program AR untuk pembelajaran interaktif. Dalam pembahasannya akan di bagi menjadi beberapa bagian :

\subsection{Fungsi Sistem}

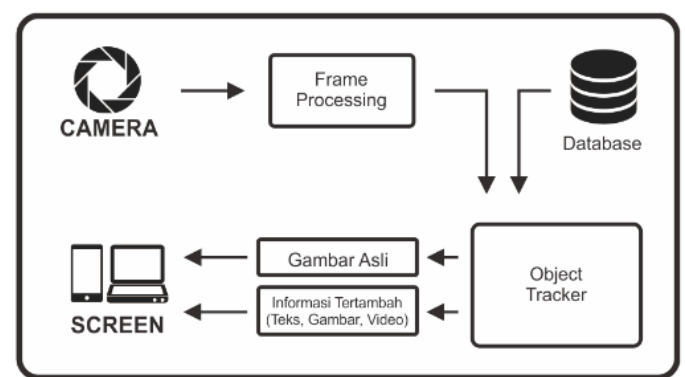

Gambar 4. Arsitektur Aplikasi AR[6]

Berdasarkan Gambar 4 dapat dilihat alur berjalan dari aplikasi AR yang dikembangkan. Pengguna hanya cukup mengarahkan objek marker ke webcam atau kamera belakang handphone. Kemudian akan di tampil objek 3D, pada layar device yang digunakan.

\subsection{Proses Pembacaan Penanda (Marker)}

Dalam percobaan ini, konsep prototipe Program AR ditunjukkan pada Gambar 5 untuk platform komputer dan android yang memiliki fitur yang sama pada kedua platform tersebut. Pengguna akan mendapatkan penanda/marker dalam bentuk gambar, kemudian marker tersubut diarahkan pada kamera dari device yang digunakan maka akan muncul objek 3D, pada layar device pengguna sesuai dengan objek marker yang dipilih.

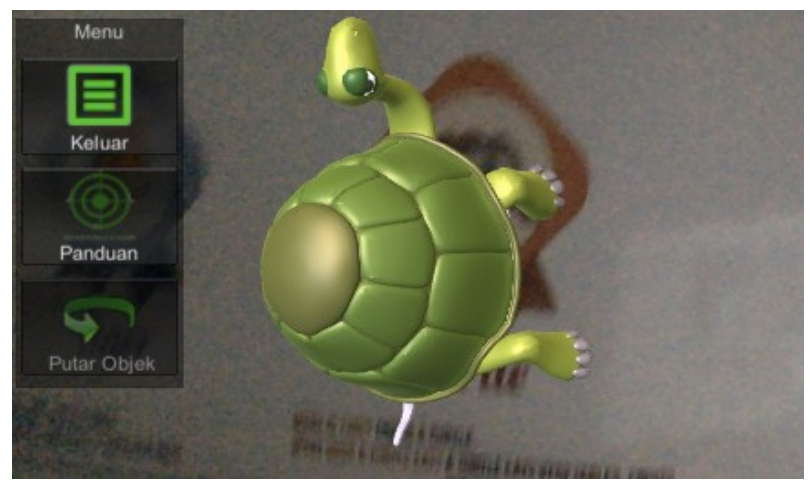

Gambar 5. Sistem deteksi gambar Aplikasi AR

Desain marker yang dikembangkan berupa Magic Book, di mana kumpulan dari beberapa marker yang di desain tersimpan dalam satu buku ajar bagi para guru, orang tua (pengguna). Dalam desain magic book ini disertakan penjelasan tentang karakter dari objek marker tersebut, misalnya untuk karakter hewan ditampilkan jenis makan dari objek tersebut. Dalam desain magic book, selain digunakan sebagai marker untuk aplikasi AR, dapat juga digunakan sebagai media mewarnai pagi para pengguna. Karena desain dari magic book menyertakan juga halaman/gambar yang dikhususkan untuk mewarnai objek tersebut. Diharapakan selain mengenali objek-objek guru/orang tua juga dapat mengarakan pengguna untuk melatih kreatifitas dalam hal mewarnai objek yang dimaksud. Perhatikan gambar 6 contoh marker aplikasi AR. 


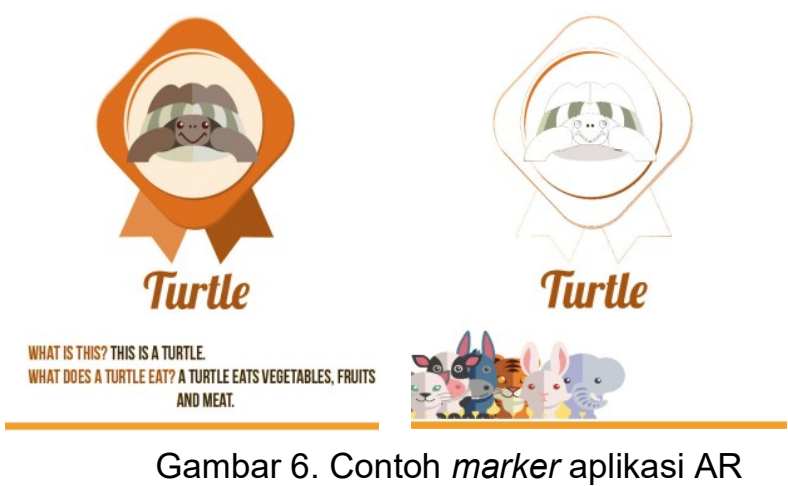

Fitur lain dari aplikasi AR ini adalah pengguna dapat memutar objek 3D $360^{\circ}$, sehingga pengguna dapat secara detail mengamati objek 3D yang ditampilkan gambar 7 . Untuk beberapa karakter hewan akan diperdengarkan suara dari karakter objek tersebut, sehingga suasana pembelajarannya akan sangat menarik.

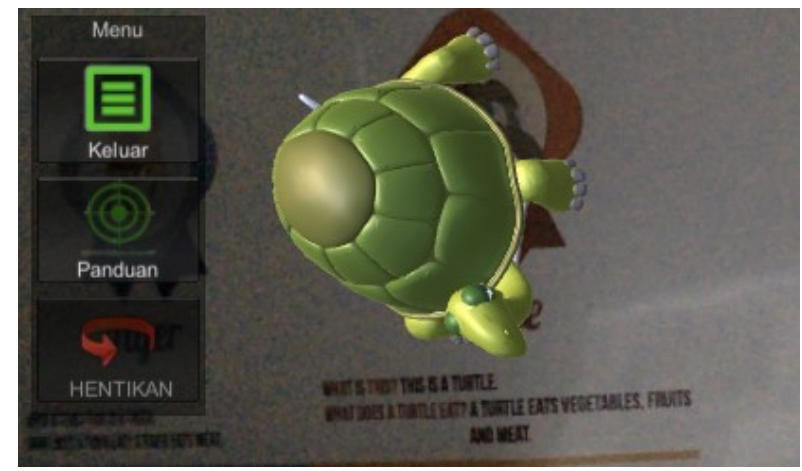

Gambar 7. Objek 3D berputar $360^{\circ}$

\subsection{Study Observasi}

Studi observasi pengembangan prototipe Aplikasi AR ini didasarkan pada masukan dari beberapa mitra lembaga pendidikan yang berkontribusi dalam penelitian ini. Salah satu yang telah diuraikan dan menjadi problem utama adalah sulitnya menarik fokus perhatian dari anak-anak peserta didik. Namun dengan diimplementasikannya Aplikasi AR ini pada beberapa lembaga pendidikan yang digunakan sebagai contoh, respon yang di dapat cukup baik. Bahkan peserta didik lebih antusias dalam mempergunakan Aplikasi AR sebagai metode pembelajaran yang interaktif. Interaksi yang terjadi antara guru dan siswa dirasa cukup menarik karena interaksi yang terjadi sangat baik di antara guru dan siswa atau bahkan orang tua dengan anak. Pengamatan yang dilakukan selama implemetasi aplikasi AR ini, dapat dilihat kegembiraan yang terjadi saat interaksi guru dan siswa, dalam hal pengoperasiannya dirasa sangat mudah karena minimnya komplen yang terjadi selama uji coba aplikasi AR.

\section{Kesimpulan dan saran}

Makalah ini telah mempresentasikan pengembangan media pembelajaran interaktif berbasis augmented reality (AR), yang diimplemetasikan untuk pembelajaran anak-anak usia dini. Aplikasi ini dikembangkan berdasarkan masukan dan saran dari beberapa lembaga pendidikan khususnya PAUD. Sehingga diharapkan para guru dan orang tua dapat terus memberikan masukan kontenkonten yang diberikan kepada anak-anak mereka. Diharapkan dengan menciptakan pembelajaran yang interaktif dan memberikan pengalaman user experience dapat memudahkan para guru dan orang tua dalam memberikan pemahaman kepada pengguna (anak-anak). Kedepan semoga akan banyak muncul model-model pembelajaran yang lebih nyaman untuk pengguna pada abad 21 ini, sehingga para guru dan orang tua tidak lagi memberikan konten-konten pembelajaran yang monoton kepada anak-anak. 


\section{Terima Kasih}

Dalam penelitian ini, peneliti mendapatkan banyak masukan dari beberapa lembaga pendidikan anak usia dini di antaranya Lembaga Pendidikan TK Aisyah PAUD 2 Makassar, I-Khalifah Makassar, Sekolah IT Ikhtiar Makassar. Sehingga dalam kesempatan ini peneliti mengucapkan terima kasih atas masukan dan dukungannya dalam mengimplementasikan hasil penelitian ini.

\section{Daftar Pustaka}

[1] Kementerian Pendidikan dan Kebudayaan Republik Indonesia (Kemdikbud RI). Undang-Undang Republik Indonesia Nomor 20 Tahun 2003 Tentang Sistem Pendidikan Nasional. 2003.

[2] Parten, M.B. 1932. Social participation among pre-school children. Journal of Abnormal and Social Psychology, 27(3), 243-269.

[3] Milgram, P., Kishino, F. Augmented Reality: A Class of Displays on the Reality virtuality Continuum. In: SPIE Proceeding Telemanipulator and Telepresence Technologies, vol. 2351. 1994.

[4] Saurina, N. 2016. Pengembangan Media Pembelajaran untuk Anak Usia Dini menggunakan Augmented Reality. Jurnal IPTEK. Vol.20 No.1

[5] Boud, A. C., Haniff, D. J., et al. 1999. Virtual reality and augmented reality as a training tool for assembly tasks. In Information Visualization, Proceedings. IEEE International Conference on, 19991999 (pp. 32-36). doi:10.1109/iv.1999.781532.1999.

[6] Yudiantika, A, R. Pasinggi, E, S. Sari, I, P. Hantono, B, S. 2013. Implementasi Augmented Reality di Museum : Studi Awal Perancangan Aplikasi Edukasi untuk Pengunjung Museum. Proceeding of KNASTIK. 